\title{
DETERMINATION OF MAGNESIUM IN PORTLAND CEMENT AND SIMILAR MATERIALS BY THE USE OF 8-HYDROXYQUINOLINE
}

\author{
By J. C. Redmond and H. A. Bright
}

\section{ABSTRACT}

The precipitation of magnesium by the use of the reagent 8-hydroxyquinoline and titration of the acid solution of the precipitate with standard bromatebromide solution have been studied. A procedure is given for determining magnesium in Portland cement. The method is accurate and much more rapid than the standard phosphate method.

\section{CONTENTS}

I. Introduction

II. General considerations

III. Experimental study

IV. The method for Portland cement.

1. Solutions required.

2. Procedure

V. Acknowledgment

\section{INTRODUCTION}

In the method used most commonly for the determination of magnesium the latter is precipitated as magnesium ammonium phosphate. To obtain accurate results the solution containing the precipitate must be allowed to stand three to four hours, and furthermore reprecipitation ${ }^{1}$ is necessary.

The maximum amount of magnesia $(\mathrm{MgO})$ allowed by Federal specification 1a and the Standard Specification for Portland Cement (C 9-26) of The American Society for Testing Materials is 5.00 per cent (plus a tolerance of 0.4 per cent). Since a great deal of cement is purchased under these specifications, it follows that many determinations of magnesia are required. At present the phosphate method is standard, and is quite accurate and applicable for umpire analyses, but it is rather lengthy. Hence a more rapid procedure for the determination of magnesium in Portland cement is desirable, especially for routine work. The work of Berg and others indicated that 8-hydroxyquinoline might be used to advantage in a rapid method for this determination and accordingly the use of this reagent for precipitating magnesium was investigated.

Based on the results of the study a procedure has been developed for determining magnesium in Portland cements and similar materials containing not more than 5.4 per cent magnesia. In the method described, the magnesium is precipitated with 8-hydroxyquinoline and the acid solution of the precipitate is titrated with a standard solution of potassium bromate-bromide.

\footnotetext{
1 Hillebrand and Lundell, Applied Inorganic Analysis, Wiley \& Sons, pp. 512-513.
} 


\section{GENERAL CONSIDERATIONS}

A number of papers have been published recently on the use of 8-hydroxyquinoline for the separation and determination of certain elements. ${ }^{2}$ Berg states that magnesium may be precipitated in the presence of iron and aluminum in a sodium hydroxide-sodium tartrate solution. Calcium, however, accompanies the magnesium in this separation. Berg further shows that magnesium may be precipitated in the presence of calcium in a faintly ammoniacal solution, but his data indicate that reprecipitation is always necessary. These facts show that no saving of time could be made by the use of these procedures and hence it is preferable to remove the iron and aluminum with ammonium hydroxide and the calcium with ammonium oxalate as is done in the standard methods.

Rapid determinations of calcium in Portland cement can be made by direct precipitation of calcium by oxalic acid, ${ }^{3}$ in the presence of iron and aluminum. Whether a direct precipitation of magnesium by 8-hydroxyquinoline can be made in the filtrate from such a separation of calcium was not investigated at this time. In the work discussed herein, the usual methods of separating iron and aluminum with ammonium hydroxide and calcium with ammonium oxalate were employed.

The determination of magnesium by the use of 8-hydroxyquinoline is based on the fact that magnesium and 8-hydroxyquinoline combine in dilute ammoniacal solution to form an insoluble compound, magnesium oxyquinolate, $\mathrm{Mg}\left(\mathrm{C}_{9} \mathrm{H}_{6} \mathrm{ON}\right)_{2} \cdot 2 \mathrm{H}_{2} \mathrm{O}$. The precipitate is crystalline and is easily filtered and washed. It may be weighed ${ }^{4}$ as anhydrous magnesium oxyquinolate after drying at $130^{\circ}$ to $140^{\circ} \mathrm{C}$., titrated according to Koppenschaar's method for the titration of phenol, ${ }^{5}$ or ignited under a cover of oxalic acid to magnesium oxide. ${ }^{6}$ The work reported in this paper was confined chiefly to the titration method, since it was found that under the proper conditions the results were as accurate as those obtained by weighing, and could be arrived at much more rapidly.

Two different procedures for the precipitation of magnesium oxyquinolate are described by Berg. ${ }^{7}$ In the first of these, the solution of the magnesium salt, containing sufficient ammonium chloride or acetate to prevent the formation of magnesium hydroxide, is made distinctly ammoniacal by adding an excess of several milliliters of concentrated ammonium hydroxide, warmed to $60^{\circ}$ to $70^{\circ} \mathrm{C}$, and the magnesium precipitated by adding a small excess of 2 per cent alcoholic or acetic acid solution of 8-hydroxyquinoline while the solution is gradually heated to the boiling point. The presence of an excess of reagent is indicated by the appearance of a yellow color in the solution. After settling, the precipitate is filtered, washed with hot dilute ammonium hydroxide (1 per cent), and either dried and weighed, or dissolved in acid and titrated. This procedure is here-

Berg., Z. Anal. Chem., 70, p. 34; 1927; 71, pp. 23, 369; 1927. Berg. Pharm. Zeit., 1929. Hahn and Vieweg. Z. A nal. Chem., 71, p. 122; 1927. J. Robitschek, J. Am. Cer. Soc., 11, p. 587; 1928. .Lundell and Knowles, B. S. Jour. Research, 3, p. $91 ; 1929$.

I. K. Meade, Portland Cement, p. 189; 1906.

- In which case the precipitate should be filtered on a Jena glass or Gooch crucible.

- Koppenschaar, Z. Anal. Chem., 15, p. 223; 1876.

Hillebrand and Lundeli, Applied Inorganie Analysis, Wiley \& Sons, p. 115.

7 Z. Anal. Chem., 71, p. 27; 1927. 
after referred to as procedure 1. In the second procedure ${ }^{8}$ an excess of 8-hydroxyquinoline solution is added to the acid solution containing the magnesium and sufficient ammonium salts to prevent the precipitation of magnesium hydroxide. The solution is then heated to boiling, and an excess ( 2 to $3 \mathrm{ml}$ ) of concentrated ammonium hydroxide is added. The supernatant liquid should be yellow. If not, more 8-hydroxyquinoline is added until the yellow color is obtained. After settling, the precipitate is filtered, and treated as in procedure 1. This procedure is designated hereinafter as procedure 2.

It will be noted that the essential difference between the two methods of precipitation is that in procedure 1 the magnesium is precipitated by adding the reagent to an ammoniacal solution while in procedure 2 ammonium hydroxide is added to an acid solution to which the reagent has previously been added.

\section{EXPERIMENTAL STUDY}

For studying the conditions affecting the precipitation of magnesium by 8-hydroxyquinoline various amounts of a standard solution of magnesium chloride were used. This standard solution was prepared from magnesium chloride of good reagent quality and was standardized by precipitating the magnesium as magnesium ammonium phosphate, reprecipitating, and igniting to the pyrophosphate. The titration procedure and the solutions of 8-hydroxyquinoline, potassium-bromide, etc., were those described later under the method for Portland cement.

The results of preliminary tests showed that boiling the solutions was not entirely satisfactory in that the magnesium oxyquinolate tends to creep, and the reagent tends to volatilize, but that the elimination of the heating to boiling produced low results. Stirring was found to accelerate precipitation. It was noted that if a large excess of reagent was added results were high. It was further noted that the time required for complete precipitation was influenced by the conditions under which the 8-hydroxyquinoline was added.

A series of experiments was accordingly made in which the acid solution, containing an excess of 8-hydroxyquinoline, was made ammoniacal. All test solutions also contained ammonium salts and a small amount of ammonium oxalate to simulate the conditions under which the magnesium precipitation is usually carried out in the analysis of Portland cement. Some of the tests were made exactly as described in procedure 2, while others, precipitated similarly, were digested for longer periods of time. All precipitations in this series and the following ones were made in a volume of about $350 \mathrm{ml}$, which is approximately that of the filtrate from the calcium determination in the analysis of Portland cement. The results are given in Table 1.

8 Pharm. Zeit.; 1929. 
TABLE 1.-Results for $\mathrm{MgO}$ obtained by adding an excess of $\mathrm{NH}_{4} \mathrm{OH}$ to an acid solution containing 8-hydroxyquinoline

[Procedure 2]

\begin{tabular}{|c|c|c|c|c|c|c|c|}
\hline $\begin{array}{l}\text { Experi- } \\
\text { ment } \\
\text { No. }\end{array}$ & $\begin{array}{l}\mathrm{MgO} \\
\text { taken }\end{array}$ & $\begin{array}{l}\mathrm{MgO} \\
\text { found }\end{array}$ & Error & $\begin{array}{l}\text { Reagent } \\
\text { added }\end{array}$ & $\begin{array}{l}\text { Approxi- } \\
\text { mate } \\
\text { reagent } \\
\text { required }\end{array}$ & $\begin{array}{c}\text { Approxi- } \\
\text { mate } \\
\text { excess }\end{array}$ & Remarks \\
\hline & $\begin{array}{r}g \\
0.0048 \\
.0120 \\
.0288\end{array}$ & $\begin{array}{l}g \\
0.0038 \\
.0081 \\
.0241\end{array}$ & $\begin{array}{r}g \\
-0.0012 \\
-.0039 \\
-.0037\end{array}$ & $\begin{array}{l}m l \\
20 \\
20 \\
20\end{array}$ & $\begin{array}{r}m l \\
3 \\
7 \\
17\end{array}$ & $\begin{array}{r}m l \\
17 \\
13 \\
3\end{array}$ & $\begin{array}{l}\text { Filtered } 15 \text { minutes after addition } \\
\text { of reagent. }\end{array}$ \\
\hline $\begin{array}{l}4 \\
5 \\
6\end{array}$ & $\begin{array}{l}.0048 \\
.0120 \\
.0288\end{array}$ & $\begin{array}{l}.0037 \\
.0112 \\
.0273\end{array}$ & $\begin{array}{l}-.0011 \\
-.0008 \\
-.0015\end{array}$ & $\begin{array}{l}20 \\
20 \\
20\end{array}$ & $\begin{array}{r}3 \\
7 \\
17\end{array}$ & $\begin{array}{r}17 \\
13 \\
3\end{array}$ & $\begin{array}{l}\text { Solution digested for } 1 \text { hour on } \\
\text { steam bath. }\end{array}$ \\
\hline & $\begin{array}{l}.0048 \\
.0120 \\
.0288\end{array}$ & $\begin{array}{l}.0047 \\
.0119 \\
.0287\end{array}$ & $\begin{array}{l}-.0001 \\
=.0001 \\
-.0001\end{array}$ & $\begin{array}{l}20 \\
20 \\
20\end{array}$ & $\begin{array}{r}3 \\
7 \\
17\end{array}$ & $\begin{array}{r}17 \\
13 \\
3\end{array}$ & $\begin{array}{l}\text { Solution digested for } 2 \text { hours on } \\
\text { steam bath and then allowed to } \\
\text { stand at room temperature over } \\
\text { night. }\end{array}$ \\
\hline
\end{tabular}

In a second series of tests the 8-hydroxyquinoline reagent was added to the warm ammoniacal solution; that is, accerding to procedure 1 . The results are shown in Table 2.

TABLE 2.-Results for $M g O$ obtained by adding an excess of 8-hydroxyquinoline to an ammoniacal solution

[Procedure 1]

\begin{tabular}{|c|c|c|c|c|c|c|}
\hline Experiment No. & $\begin{array}{c}\mathrm{MgO} \\
\text { taken }\end{array}$ & $\begin{array}{l}\mathrm{MgO} \\
\text { found }\end{array}$ & Error & $\begin{array}{l}\text { Reagent } \\
\text { added }\end{array}$ & $\begin{array}{l}\text { Approxi- } \\
\text { mate } \\
\text { reagent } \\
\text { required }\end{array}$ & $\begin{array}{l}\text { Approxi- } \\
\text { mate } \\
\text { excess }\end{array}$ \\
\hline 112 & $\begin{array}{l}g \\
0.0048 \\
.0049 \\
.0120 \\
.0121\end{array}$ & $\begin{array}{l}g \\
0.0043 \\
.0048 \\
.0115 \\
.0115\end{array}$ & $\begin{array}{r}g \\
-0.0005 \\
-.0001 \\
-.0005 \\
-.0006\end{array}$ & $\begin{array}{l}m l \\
20 \\
28 \\
20 \\
22\end{array}$ & $\begin{array}{l}m l \\
3 \\
3 \\
7 \\
7 \\
7\end{array}$ & $\begin{array}{ll}m l & \\
17 \\
25 \\
13 \\
15\end{array}$ \\
\hline 16 & $\begin{array}{l}.0121 \\
.0121 \\
.0170 \\
.0288\end{array}$ & $\begin{array}{l}.0120 \\
.0123 \\
.0166 \\
.0272\end{array}$ & $\begin{array}{l}-.0001 \\
+.0002 \\
-.0004 \\
-.0016\end{array}$ & $\begin{array}{r}32 \\
-\quad 40 \\
31 \\
20\end{array}$ & $\begin{array}{r}7 \\
7 \\
10 \\
17\end{array}$ & $\begin{array}{r}25 \\
33 \\
21 \\
3\end{array}$ \\
\hline $\begin{array}{l}18 \\
19 \\
20\end{array}$ & $\begin{array}{l}.0291 \\
.0291 \\
.0291\end{array}$ & $\begin{array}{r}.0294 \\
.0293 \\
1.0297\end{array}$ & $\begin{array}{l}+.0003 \\
+.0002 \\
+.0006\end{array}$ & $\begin{array}{l}31 \\
40 \\
20\end{array}$ & $\begin{array}{l}17 \\
17 . \\
17\end{array}$ & $\begin{array}{r}14 \\
23 \\
3\end{array}$ \\
\hline
\end{tabular}

I Stirring substituted for boiling.

As previously mentioned, complete precipitation was obtained in much less time when the solutions were stirred. Furthermore, a much smaller excess of reagent was requred for complete precipitation in a short time. It was observed, however, that high values were obtrined when the hot ammoniacal solution was stirred and the 8-hydroxyquinoline added until a precipitate first appeared. Under these conditions which correspond essentially to those of procedure 1 , with the exception that stirring is substituted for "the heating to boiling," a considerable excess of reagent must be added before the precipitate begins to form. The results obtained when the heating to boiling was replaced by stirring in procedure 2 were satisfactory, since only small positive errors were noted with the same excess of reagent that caused large errors in the previously mentioned case. 
This latter method will be designated as procedure 3 , and is carried out as follows: All of the reagent is added to a warm $\left(60^{\circ}\right.$ to $70^{\circ} \mathrm{C}$.) neutral or faintly ammoniacal solution, and an excess of ammonium hydroxide of 3 to $4 \mathrm{ml}$ per $100 \mathrm{ml}$ of the solution is added. The solution is then stirred for 10 minutes. The results obtained by this method of precipitation, procedure 3 , are given in Table 3.

TABLE 3.-Results for $M g O$ obtained by adding an excess of 8-hydroxyquinoline reagent to the neutral (or slightly ammoniacal) solution at $60^{\circ}$ to $70^{\circ}$ C.. then a 3 to \& per cent excess of $\mathrm{NH}_{4} \mathrm{OH}$, then stirring for 10 to 15 minutes

[Procedure 3]

\begin{tabular}{|c|c|c|c|c|c|c|}
\hline Experiment No. & $\begin{array}{l}\mathrm{MgO} \\
\text { taken }\end{array}$ & $\begin{array}{l}\mathrm{MgO} \\
\text { found }\end{array}$ & Error & $\begin{array}{l}\text { Reagent } \\
\text { added }\end{array}$ & $\begin{array}{c}\text { Approxi- } \\
\text { mate } \\
\text { reagent } \\
\text { required }\end{array}$ & $\begin{array}{c}\text { Approxi- } \\
\text { mate } \\
\text { excess }\end{array}$ \\
\hline $\begin{array}{l}21 \\
22 \\
24 \\
24\end{array}$ & $\begin{array}{r}g \\
0.0048 \\
.0120 \\
.0120 \\
.0123\end{array}$ & $\begin{array}{r}g \\
0.0052 \\
.0123 \\
.0129 \\
1.0124\end{array}$ & $\begin{array}{r}g \\
+0.0004 \\
+.0003 \\
+.0009 \\
+.0001\end{array}$ & $\begin{array}{r}m l \\
20 \\
20 \\
35 \\
32\end{array}$ & $\begin{aligned} & m l \\
& 3 \\
& 7 \\
& 7 \\
& 7\end{aligned}$ & $\begin{array}{ll}m l & \\
17 \\
13 \\
28 \\
25\end{array}$ \\
\hline 25 & $\begin{array}{l}.0170 \\
.0240 \\
.0224 \\
.0288\end{array}$ & $\begin{array}{r}.0172 \\
.0260 \\
1.0223 \\
.0288\end{array}$ & $\begin{array}{r}+.0002 \\
+.0020 \\
+.0001 \\
.0000\end{array}$ & $\begin{array}{l}20 \\
40 \\
40 \\
20\end{array}$ & $\begin{array}{l}10 \\
14 \\
14 \\
17\end{array}$ & $\begin{array}{r}10 \\
26 \\
26 \\
3\end{array}$ \\
\hline
\end{tabular}

1 Precipitate dried 1 hour at $130^{\circ}$ to $140^{\circ} \mathrm{C}$. before titration.

Passing on to a further consideration of the data given in Tables 1, 2, and 3, the following will be observed: In Table 1 experiments 1 to 3 show that with $20 \mathrm{ml}$ of the 8-hydroxyquinoline solution $(1.25$ per cent) complete precipitation of magnesium was not secured in 15 minutes when the acid solution of magnesium and 8-hydroxyquinoline is treated with ammonium hydroxide (procedure 2). With additional digestion and long standing, precipitation is complete. Twenty milliliters of the reagent 8-hydroxyquinoline is theoretically more than sufficient to precipitate from a 0.5 sample, the maximum amount of magnesia (5.4 per cent) allowed by either the Federal specification No. 1 a for Portland Cement, or The American Society for Testing Materials Specification for Portland Cement (C 9-26). ${ }^{\circ}$

In Table 2, experiments 10,12 , and 17 also show that $20 \mathrm{ml}$ of 8hydroxyquinoline reagent is not sufficient to secure complete precipitation of magnesium when the 8-hydroxyquinoline reagent is added to the ammoniacal solution (procedure 1), though precipitation is more nearly complete than in the case when ammonium hydroxide was added to the acid solution of magnesium containing the 8hydroxyquinoline reagent. Increasing the excess of reagent aids in securing complete precipitation within a short time. With an excess of approximately $25 \mathrm{ml}$ of 8-hydroxyquinoline reagent small amounts of magnesium are completely precipitated by procedure 1 (experiments 11, 14, and 19). Furthermore, this excess of reagent does not introduce any serious positive error when $0.0291 \mathrm{~g}$ of magnesia are present as shown by experiment 19. With a cement of unknown magnesium content, it is therefore possible, when using this procedure to add from 35 to $40 \mathrm{ml}$ of the reagent, thereby insuring complete precipitation for cements low in magnesia and at the same time intro-

A. S. T. M. Standards II, p. 27; 1927. 
ducing no serious positive error for those cements approaching the maximum amount $(0.0270 \mathrm{~g}$ for a 0.5 sample) of magnesia allowed by the standard specifications. A comparison of the results of experiments 17 and 20 shows the effect of stirring in hastening complete precipitation. A further comparison of experiment 20 with 28 shows the positive error introduced by the stirring procedure when the 8hydroxyquinoline reagent is added to a hot ammoniacal solution.

In Table 3, it will be noted (experiment 28) that $20 \mathrm{ml}$ of the 8 -hydroxyquinoline reagent is sufficient to precipitate $0.0288 \mathrm{~g}$ of magnesia when added to a neutral or faintly ammoniacal solution, followed by the addition of an excess of 3 to 4 per cent of ammonium hydroxide and stirring of the solution for 10 to 15 minutes (procedure 3). Excess reagent apparently tends toward larger positive errors in this procedure (procedure 3). As indicated in experiments 21, 22 and 25 , the error, when $20 \mathrm{ml}$ of reagent is added, is negligible for commercial analyses. These positive errors are probably due to occluded reagent and can be avoided if the precipitate is dried at $130^{\circ}$ to $140^{\circ} \mathrm{C}$. before it is weighed or titrated since 8-hydroxyquinoline is volatile at these temperatures. Experiments 24 and 27 support this view.

From the preceding discussion it is evident that less reagent is required for complete precipitation in a short time if the solution is stirred. Furthermore, in cases where the approximate magnesia content of a cement is not known, it is satisfactory to add $20 \mathrm{ml}$ of the reagent, since this amount gives satisfactory results for quantities of magnesia from 0.0048 to $0.0288 \mathrm{~g}$. This procedure has accordingly been adopted in the method to be described. In this method silica need not be removed and only single precipitations of iron and aluminum, and of calcium are made. The very small amount of magnesia which may be occluded in the $\mathrm{R}_{2} \mathrm{O}_{3}$ and calcium precipitates is apparently compensated for by the tendency of the method to give results which are a few tenths of a milligram high.

TABLE 4.-Results obtained by recommended procedure on standard argillaceous limestone No. 1 a

\begin{tabular}{|c|c|c|c|c|}
\hline Experiment No. & $\begin{array}{l}\text { Weight of } \\
\text { sample }\end{array}$ & $\underset{\text { present }}{\mathrm{MgO}}$ & $\begin{array}{l}\mathrm{MgO} \\
\text { found }\end{array}$ & Error \\
\hline $\begin{array}{l}29 \\
30 \\
31 \\
32 \\
33 \\
34\end{array}$ & $\begin{array}{r}0.5 \\
.5 \\
.8 \\
.8 \\
.8 \\
.8\end{array}$ & $\begin{array}{l}0.0109 \\
.0109 \\
.0175 \\
.0175 \\
.0175 \\
.0175\end{array}$ & $\begin{array}{l}0.0 \\
.0108 \\
.0109 \\
.0174 \\
.0176 \\
.0176 \\
.0177\end{array}$ & $\begin{array}{r}g \\
-0.0001 \\
.0000 \\
-.0001 \\
+.0001 \\
+.0001 \\
+.0002\end{array}$ \\
\hline
\end{tabular}

The performance of the method is illustrated by the data given in Table 4. Since the bureau issues no standard analyzed sample of Portland cement because of the inconstancy of the chemical composition of this material, and since the preparation of such a standard for this work would have involved a large number of determinations, samples of Bureau of Standards standard argillaceous limestone No. 1a were used to test the results obtained with the method. This limestone, when ignited in a platinum crucible for 30 minutes at $1,100^{\circ} \mathrm{C}$., has a composition very similar to Portland cement. After this 
ignition, the samples were dissolved in hydrochloric acid, and the magnesia was then determined by the recommended method. By using the method described below an experienced operator can determine magnesia in a Portland cement or limestone in 1.5 to 2 hours.

\section{THE METHOD FOR PORTLAND CEMENT}

\section{SOLUTIONS REQUIRED}

Acetic acid solution of 8-hydroxyquinoline (1.25 per cent).-Dissolve $25 \mathrm{~g}$ of 8-hydroxyquinoline in $60 \mathrm{ml}$ of glacial acetic acid. When solution is complete dilute to a volume of 2 liters with cold water. One milliliter of this solution is equivalent to $0.0016 \mathrm{~g}$ of $\mathrm{MgO}$.

Potassium bromate-bromide solution (0.2 N).-Dissolve $20.00 \mathrm{~g}$ of potassium bromide and $5.57 \mathrm{~g}$ of potassium bromate in $200 \mathrm{ml}$ of water and dilute to 1 liter. The ratio of this solution to the standard sodium thiosulphate solution is obtained as follows: To $200 \mathrm{ml}$ of water in a $400-\mathrm{ml}$ beaker add $20 \mathrm{ml}$ of hydrochloric acid (specific gravity 1.19) and then exactly $25 \mathrm{ml}$ of the potassium bromatebromide solution. Add immediately $10 \mathrm{ml}$ of the potassium iodide solution and titrate with the standard sodium thiosulphate solution until the solution is nearly colorless. Then add $2 \mathrm{ml}$ of starch solution and titrate to the disappearance of the blue color.

Sodium thiosulphate solution $(0.1 \mathrm{~N})$.-Dissolve $25 \mathrm{~g}$ of sodium thiosulphate $\left(\mathrm{Na}_{2} \mathrm{~S}_{2} \mathrm{O}_{3} .5 \mathrm{H}_{2} \mathrm{O}\right)$ in $200 \mathrm{ml}$ of water, and dilute to 1 liter. Standardize this solution with a $0.1 \mathrm{~N}$ solution of resublimed iodine. The iodine solution is standardized with Bureau of Standards standard sample of arsenious oxide No. 83. One milliliter of an exactly $0.1 \mathrm{~N}$ sodium thiosulphate solution is equivalent to $0.000504 \mathrm{~g}$ of $\mathrm{MgO}$.

Potassium iodide solution (25 per cent).-Dissolve $25 \mathrm{~g}$ of potassium iodide in $100 \mathrm{ml}$ of water.

Starch solution.-Dissolve $5 \mathrm{~g}$ of soluble starch and $2.5 \mathrm{~g}$ of salicylic acid in 1 liter of water.

\section{PROCEDURE}

To a $0.500 \mathrm{~g}$ sample in a $400 \mathrm{ml}$ beaker add $10 \mathrm{ml}$ of water and $10 \mathrm{ml}$ of hydrochloric acid (specific gravity 1.19). Heat gently, and grind any coarse particles with the flattened end of a glass rod until decomposition is complete. Dilute to $150 \mathrm{ml}$ with hot water.

To the solution add three drops of methyl red indicator $(0.2$ per cent alcoholic solution), and then ammonium hydroxide (specific gravity 0.90) until the solution is distinctly yellow. Add macerated filter paper and heat to boiling. Boil for one to two minutes, remove from the hot plate, and allow the solution to stand until the precipitate has settled. Filter without delay and wash the precipitate thoroughly with a hot 2 per cent solution of ammonium chloride. To the filtrate add $1 \mathrm{ml}$ of ammonium hydroxide (specific gravity 0.90 ), and heat to boiling. When the solution is boiling, add $25 \mathrm{ml}$ of hot ammonium oxalate solution (4 per cent), and continue the boiling for two or three minutes. Digest on the steam bath for one-half to one hour and then filter and wash five or six times with warm water. The volume of the filtrate at this point should be about $350 \mathrm{ml}$. 
Heat the filtrate to $60^{\circ}$ to $70^{\circ} \mathrm{C}$. and add ${ }^{10} 20 \mathrm{ml}$ of the 8 -hydroxyquinoline solution, and then $4 \mathrm{ml}$ of ammonium hydroxide per $100 \mathrm{ml}$ of solution. Stir on a mechanical stirring machine for 10 to 15 minutes and set aside until the precipitate has settled. Filter and wash with hot dilute ammonium hydroxide $(1: 40)$. Dissolve the precipitate in 50 to $75 \mathrm{ml}$ of hot dilute hydrochloric acid $(1: 9)$, dilute the resulting solution to $200 \mathrm{ml}$, and add $15 \mathrm{ml}$ of hydrochloric acid (specific gravity 1.19). Cool to $25^{\circ} \mathrm{C}$. and add from a pipette $25 \mathrm{ml}$ of the standard potassium bromate-bromide solution. Add immediately $10 \mathrm{ml}$ of potassium iodide solution and titrate with the sodium thiosulphate solution until the solution clears slightly. ${ }^{11}$ Add $2 \mathrm{ml}$ of the starch solution and titrate to the disappearance of the blue color. If

The percentage of magnesia may be calculated as follows:

$A=\mathrm{g}$ of $\mathrm{MgO}$ per $\mathrm{ml}$ of the standard thiosulphate solution.

$B=\mathrm{ml}$ of thiosulphate solution equivalent to $25 \mathrm{ml}$ of the bromatebromide solution. Then

$C=\mathrm{ml}$ of thiosulphate solution required for titrating the precipitate.

For example

$$
(B-C) \times A=\mathrm{g} \text { of } \mathrm{MgO}
$$

If $25 \mathrm{ml}$ of the bromate solution required $49.85 \mathrm{ml}$ of $0.1008 \mathrm{~N}$ thiosulphate solution and $13.45 \mathrm{ml}$ of the thiosulphate solution were required for titrating the precipitate, the percentage of magnesia in a $0.5 \mathrm{~g}$ sample would be calculated thus:

$$
\begin{gathered}
(49.85-13.45) \times 0.000508=0.0185 \mathrm{~g} \mathrm{MgO} \\
0.0185 \times \frac{100}{0.5}=3.70 \text { per cent } \mathrm{MgO}
\end{gathered}
$$

\section{ACKNOWLEDGMENT}

Acknowledgment is made to R. B. Rudy, who cooperated with the senior author in preliminary tests on the use of the reagent 8-hydroxyquinoline in determining magnesia in Portland cement. Because of Mr. Rudy's assignment to other work the study of the reaction and the development of the recommended procedure were made by the senior author with the assistance of the junior author.

Washington, August 15, 1930.

10 If a mechanical stirrer is not available the following procedure may be substituter at this point: Heat the eltrate to $60^{\circ}$ to $70^{\circ} \mathrm{O}$. and add $4 \mathrm{ml}$ of ammonium hydroxide (speciflc gravity 0.90 ) per $100 \mathrm{ml}$ of solution. 'Then add $40 \mathrm{ml}$ of 8 -hydroxyquinoline solution and heat to boiling. As soon as the solution boils, set it aside until the precipitate settles, filter, and treat as in the recommended procedure.

11 The reactions involved in the titration are as follows: Hydrochloric acid reacts with the potassium bromate-bromide solution liberating free bromine according to the equation-

\section{$\mathrm{KBrO}+5 \mathrm{KBr}+6 \mathrm{HCl}=6 \mathrm{KCl}+3 \mathrm{H}_{2} \mathrm{O}+3 \mathrm{Br}_{2}$}

The freo bromine reacts with the 8-hydroxyquinoline in solution forming dibromohydroxyquinolate, a follows-

$\mathrm{C}_{8} \mathrm{H}_{7} \mathrm{OH}+2 \mathrm{Br}_{2}=\mathrm{C}_{8} \mathrm{H}_{8} \mathrm{OHBr}+2 \mathrm{HBr}$

On addition "of the potassium iodide solution the excess of free bremine is replaced by free lodine which is titrated with a standard solution of sodium thiosulphate. 